\title{
Adsorption of ammonia nitrogen by jackfruit (Artocarpus heterophyllus) seeds: Isotherms and kinetic modeling studies
}

\author{
Azreen Ibrahim *, Lija Yusof , Abu Zahrim Yaser \\ Faculty of Engineering, Universiti Malaysia Sabah, Jalan UMS, 88400 Kota Kinabalu, Sabah, Malaysia.
}

* Corresponding author: azreen@ums.edu.my

Article history

Received 19 November 2017

Accepted 6 December 2017

\begin{abstract}
Ammonia nitrogen $\left(\mathrm{NH}_{3}-\mathrm{N}\right)$ is one of the common and toxic species of nitrogen and excess of it in waterway causes eutrophication, decreased in dissolved oxygen and toxic to aquatic organisms. This study aims to investigate the isotherm and kinetic modeling of adsorption of ammonia nitrogen from aqueous solution by using jackfruit (Artocarpus heterophyllus) seed. Batch equilibrium experiments were carried out at 60 minute of contact time with initial $\mathrm{pH}$ value of 7 . The adsorption isotherm data fitted well with Langmuir model with correlation $\left(R^{2}\right)$ of 0.9809 and maximum monolayer adsorption capacitiy $\left(Q_{e}\right)$ of $3.94 \mathrm{mg} / \mathrm{g}$. Meanwhile, the adsorption of $\mathrm{NH}_{3}-\mathrm{N}$ follows pseudo second order with correlation $\left(R^{2}\right)$ values ranges from 0.62 to 0.96 for various concentrations. Besides, the adsorption capacity obtained from experiment also has the smallest difference with calculated adsorption capacity. This suggest that the adsorption is mainly governed by chemical process involving cations sharing or exchange between the adsorbent and $\mathrm{NH}_{3}-\mathrm{N}$ in the solution. In conclusion, jackfruit seed can be used as adsorbent materials for ammonia nitrogen removal from aqueous solution.
\end{abstract}

Keywords: Adsorption, ammonia nitrogen, jackfruit seed, isotherm

\section{INTRODUCTION}

Excessive amount of ammonia nitrogen in water bodies is one of major global environmental problem and this common problem may originate from diverse sources such as industry waste, agricultural runoff and landfill leachate. Over enrichment of nutrient in water ways lead to serious distortion on nature as it may results in depletion of dissolved oxygen, eutrophication and toxicity to aquatic lives (Yaser et al., 2016).

Various traditional and conventional treatment methods have been established for years to remove ammonia nitrogen contamination such as chemical precipitation, biological treatment and adsorption. Among these methods, adsorption is considered to be the most promising and effective approach as it is economical feasible, easy in operation and environmental friendly (Ibrahim et al., 2016). However, the relatively high cost of conventional adsorbent limits the usage of adsorption in wastewater treatment application. Thus, extensive studies on the renewable materials that cheaper, and abundance has been done over the past few years. The utilization of agricultural residues for adsorption process is one of the alternative technologies as it is easily available, low cost and environmental friendly. To date, the ability of agricultural waste as adsorbent for the removal of pollutant has been studied by many researchers which includes Citrus Limettioides seed and peel (Sudha et al., 2015), modified empty fruit bunch (EFB) (Lee et al., 2016) and watermelon rind (Ibrahim et al., 2016). However, there is still limited information available on the usage of local agricultural residues as adsorbent for removal of ammonia nitrogen from aqueous solution. Hence, this research work was intended to determine the adsorption isotherms and kinetic modeling of ammonia nitrogen onto the jackfruit seed. Jackfruit (Artocarpus heterophyllus) seed is an oblong cylindrical or rounded in shape and is light brown in color. The jackfruit seed is composed of moisture $(9.59 \pm 0.1 \%)$, protein $(0.09 \pm 0.03 \%)$, lipid $(0.03 \pm 0.01 \%)$, ash $(0.04 \pm 0.04 \%)$, carbohydrates $(93.64 \pm 0.73 \%)$, amylose $(25.54 \pm 0.38 \%)$ and amylopectine $(74.46 \pm 0.38 \%)(d w b)$ (Choy et al., 2017; Rengsutthi and Charoenrein, 2011).

\section{EXPERIMENTAL}

\section{Preparation of adsorbent}

The jackfruit seeds were collected from market area located in Kota Belud, Sabah. The seeds were washed thoroughly with tap water and distilled water to remove the surface adhere impurities before dried in an oven at $40^{\circ} \mathrm{C}$ for 48 hours. The seeds then grounded and sieved to smaller size around 1-2 mm.

\section{Preparation of ammonia nitrogen aqueous solution}

Ammonia nitrogen $\left(\mathrm{NH}_{3}-\mathrm{N}\right)$ aqueous solution was used throughout the experiment and prepared by dissolving ammonium chloride $\left(\mathrm{NH}_{4} \mathrm{Cl}\right)$ with calculated weight in $1 \mathrm{~L}$ of distilled water for desired concentration. The ranges of adsorbate concentrations used in this study varied between 50 to $1000 \mathrm{mg} / \mathrm{L}$ and the solution $\mathrm{pH}$ was adjusted by using $0.1 \mathrm{M}$ of sodium hydroxide $(\mathrm{NaOH})$.

\section{Batch adsorption experiment}

The experiment were conducted in batch process with initial concentration range from 50 to $1000 \mathrm{mg} / \mathrm{L}$, initial $\mathrm{pH} 7$ and 20 gram (g) of jackfruit seed. The concentration range was based on typical range of ammonia nitrogen level from landfill leachate and industrial wastewater. The concentration of solution then was analyzed at certain intervals by using UV-Vis spectrophotometer with $\mathrm{HACH}$ Spectrophotometer DR2010 brand at the maximum wavelength of 425 $\mathrm{nm}$. The amount of ammonia nitrogen adsorbed at equilibrium, $\mathrm{q}_{\mathrm{e}}$ $(\mathrm{mg} / \mathrm{g})$ was calculated as followed:

$$
Q_{e}=\left[\left(C_{o}-C_{e}\right) V\right] / W
$$


where $\mathrm{C}_{\mathrm{o}}$ and $\mathrm{C}_{\mathrm{e}}(\mathrm{mg} / \mathrm{L})$ are the liquid-phase concentrations of initial adsorbate and equilibrium, respectively. $\mathrm{V}$ is the volume of the solution $(\mathrm{L})$ and $\mathrm{W}$ is the weight of the adsorbent $(\mathrm{g})$.

\section{Adsorption isotherm and kinetic studies}

The equilibrium isotherm study was conducted by adding $20 \mathrm{~g}$ of jackfruit seed into a $500 \mathrm{mg} / \mathrm{L}$ of ammonia nitrogen solution with adjusted $\mathrm{pH}$ 7.0. The residual concentration of ammonia nitrogen was analyzed until it reaches equilibrium and the data were fitted to different isotherm models; Langmuir, Freundlich, Temkin and Dubinin-Radushkevich (D-R) models.

Meanwhile, the adsorption kinetic study was carried out at various solution concentrations $(50,100,500$ and $1000 \mathrm{mg} / \mathrm{L})$ wherein the extent of adsorption was investigated as a function of time. The experimental result then was fitted to pseudo first order, pseudo second order and intra-particle diffusion model. The best fit models for both isotherm and kinetic studies were selected based on the highest coefficient correlation $\left(\mathrm{R}^{2}\right)$ and the calculated $\mathrm{q}_{\mathrm{e}}$ values. All experiment conducted in duplicate and the average result is calculated.

\section{RESULTS AND DISCUSSION}

\section{Adsorption isotherm studies}

Screening experiment was conducted on 40 types of potential adsorbent derived from agricultural wastes. The adsorption capacity, reoval rate and zeta potential value of each adsorbents were determined and the results obtained are tabulated in Table 1. Jackfruit seed was selected as the best adsorbent and used for further sorption studies due to the high adsorption capacity and its availability througout the years.

Table 1 Adsorption capacity and removal rate of 40 local biosorbent (Ibrahim et al., 2017).

\begin{tabular}{|c|c|c|c|c|c|}
\hline Agricultural wastes & Scientific Name & $\begin{array}{l}\text { Removal } \\
\text { rate (\%) }\end{array}$ & $\begin{array}{l}\text { Adsorption } \\
\text { capacity }(\mathrm{mg} / \mathrm{g})\end{array}$ & $\begin{array}{l}\text { Zeta potential } \\
(\mathrm{mV})\end{array}$ & Season (month) \\
\hline Banana peel & Musa Acuminata & 8.22 & 1.51 & -27.4 & Jan-Dec \\
\hline Banana comb & Musa Acuminata & 7.03 & 0.88 & -51.37 & Jan-Dec \\
\hline Papaya peel & Carica Papaya & -4.96 & -0.81 & -32.4 & Jan-Dec \\
\hline Papaya seed & Carica Papaya & -17.3 & -3.03 & -31.6 & Jan-Dec \\
\hline Pomelo peel & Citrus Maxima & 13.95 & 1.74 & -29.0 & Aug-Oct /Jan-March \\
\hline Pineapple peel & Ananas Comosus & -39.07 & -4.88 & -12.4 & Jan-Dec \\
\hline Pineapple stem & Ananas Comosus & 2.93 & 1.07 & -14.0 & Jan-Dec \\
\hline Langsat (Lanzones) peel & Lansium Domesticum & 28.67 & 3.59 & -36.3 & Jun-July / Nov -Feb \\
\hline Langsat (Lanzones) seed & Lansium Domesticum & 5.36 & 0.79 & -48.3 & Jun-July / Nov -Feb \\
\hline Soursop peel & Annona Muricata & -1.96 & -0.25 & -22.4 & March- April / June-July \\
\hline Coconut coir & Cocos Nucifera & 12.73 & 1.59 & -37.9 & Jan-Dec \\
\hline Sugarcane bagasse & Saccharum Officinarum & 3.67 & 1.59 & -20.3 & Jan-May \\
\hline Corn (silk) & Zea Mays & -3.74 & -4.68 & -37.87 & Jan-Dec \\
\hline Corn (shank) & Zea Mays & -7.56 & -0.95 & -22.75 & Jan- Dec \\
\hline Corn comb & Zea Mays & -10.45 & -1.56 & -23.7 & Jan-Dec \\
\hline Corn husk leaf & Zea Mays & 5.55 & 0.69 & -20.15 & Jan- Dec \\
\hline Passion fruit & Passiflora Edulis & 6.34 & 0.79 & -35.1 & Nov-April \\
\hline Cassava peel & Manihot Esculenta & 5.81 & 0.73 & -40.11 & Jan-Dec \\
\hline $\begin{array}{l}\text { Banana false stem } \\
\text { (Pseudostem) }\end{array}$ & Musa Acuminata & -3.14 & -0.39 & -32.6 & Jan-Dec \\
\hline Sapodilla peel & Manilkara Zapota & -73.16 & -9.32 & -11.9 & Jan-Dec \\
\hline Limau madu (Citrus) peel & Citrus Suhuiensis & 15.59 & 1.95 & -38.05 & March-April / Oct-Nov \\
\hline Jackfruit peel & Artocarpus Heterophyllus & 16.26 & 2.03 & -18.03 & Jan- Dec \\
\hline Jackfruit seed & Artocarpus Heterophyllus & 26.96 & 3.3702 & -24.8 & Jan- Dec \\
\hline Areca palm & Areca Catechu & -4.32 & -0.54 & -31.9 & Jan- Dec \\
\hline Coconut mesocarp & Cocs Nucifera & -72.0 & -10.08 & -29.7 & Jan -Dec \\
\hline Honey Dew Peel & Cucumis melo var. inodorus & -5.79 & -0.72 & -27.2 & Jan- Dec \\
\hline Purple Yam peel & Dioscorea Alata & -43.05 & -5.38 & -47.1 & Jan-Dec \\
\hline Mango seed & Mangifera Indica & -78.65 & -9.78 & -42.07 & Jan-Dec \\
\hline Mango peel & Mangifera Indica & -3.74 & -0.47 & -26.23 & Jan-Dec \\
\hline Sweet potato peel & Ipomoea Batatas & 6.97 & 0.87 & -19.53 & Jan-Dec \\
\hline $\begin{array}{l}\text { Cat's Eye (Mata Kucing) } \\
\text { peel }\end{array}$ & Euphoria Malaiense & -52.93 & -6.62 & -27.1 & Jan-Feb \\
\hline $\begin{array}{l}\text { Cat's Eye (Mata Kucing) } \\
\text { seed }\end{array}$ & Euphoria Malaiense & -2.37 & -0.36 & -28.4 & Jan-Feb \\
\hline Moringa peel (young) & Moringa Oleifera & -76.33 & -9.54 & -42.33 & Jan-Dec \\
\hline Moringa seed (young) & Moringa Oleifera & -6.99 & -0.87 & -28.37 & Jan-Dec \\
\hline Moringa peel (mature) & Moringa Oleifera & 21.09 & 2.64 & -44.07 & Jan-Dec \\
\hline Moringa seed (mature) & Moringa Oleifera & -7.35 & -0.92 & -9.47 & Jan-Dec \\
\hline Breadnut stem & Artocarpus Camansi & -4.32 & -0.64 & -25.8 & Jan-Dec \\
\hline Breadnut peel & Artocarpus Camansi & 10.97 & 1.37 & -35.2 & Jan-Dec \\
\hline Bambangan peel & Mangifera Pajang & 4.67 & 0.58 & -21.8 & May-Nov \\
\hline Bitter bean (Petai) peel & Parkia Speciosa & -1.43 & -0.18 & -50.5 & $\begin{array}{l}\text { March- April/ } \\
\text { Aug-Sept }\end{array}$ \\
\hline
\end{tabular}


The adsorption isotherms basically represent the adsorption equilibrium data that correspond to the relationship of mass of solute adsorbed per unit mass of adsorbent, $\mathrm{Q}_{\mathrm{e}}$ and the solute concentration in the solution at equilibrium, $\mathrm{C}_{\mathrm{e}}$ (Ramasamy and Krishnamoorthy, 2015). In this study, linear regression isotherm model is employed to examine the biosorption of ammonium ion onto the jackfruit seed adsorbent; Langmuir, Freundlich, Temkin and Dubinin-Radushkevich (D-R) isotherm models. Langmuir and Freundlich models usually applied to distinguish the monolayer and multilayer adsorption onto the adsorbent surface at constant temperature. Meanwhile, Temkin model used to describe the adsorption studies on which the heat of adsorption is a function of coverage. Dubinin-Radushkevich model is used to express the adsorption mechanism onto porous heterogeneous surface of adsorbent and its mean free energy (Foo and Hameed, 2010; Itodo and Itodo, 2010). In addition, several papers reported on the solid-liquid adsorption system have been using these similar models (Cengiz et al., 2012; Ma et al., 2011; Singh et al., 2017). Table 2 summarizes the parameter constants of isotherm models for the removal of ammonia nitrogen by using jackfruit seed.

Table 2 Parameter constant for isotherm models.

\begin{tabular}{lll}
\hline Isotherm model & \multicolumn{2}{c}{ Parameters } \\
\hline Langmuir & $\mathrm{Q}_{\mathrm{m}}(\mathrm{mg} / \mathrm{g})$ & 3.9425 \\
& $\mathrm{~B}$ & 0.0105 \\
& $\mathrm{R}_{\mathrm{L}}$ & 0.1606 \\
Freundlich & $\mathrm{R}^{2}$ & 0.9809 \\
& $1 / \mathrm{n}$ & 2.0708 \\
& $\mathrm{n}$ & 0.4829 \\
Temkin & $\mathrm{K}_{\mathrm{F}}$ & 0.2059 \\
& $\mathrm{R}^{2}$ & 0.9690 \\
Dubinin-Radushkevich & $\mathrm{B}$ & 0.9105 \\
& $\mathrm{~A}$ & 0.1027 \\
& $\mathrm{R}^{2}$ & 0.9598 \\
& $\mathrm{Q}_{\mathrm{D}}(\mathrm{mg} / \mathrm{g})$ & -0.0710 \\
& $\mathrm{E}$ & 0.1445 \\
& $\mathrm{R}^{2}$ & 2.6537 \\
\hline
\end{tabular}

The Langmuir isotherm model assumes that the adsorption process takes place at homogenous surface sites by monolayer sorption within the adsorbent (Jellali et al., 2011). This adsorption process can only occur at a fixed number of localized sites as the sites possess equal affinity for the adsorbate, ammonium aqueous solution in this case (Vijayaraghavan et al., 2006). No interaction occurred on neighboring sites of molecules adsorbed and the intermolecular forces decreased rapidly with distance (Gimbert et al., 2008). This isotherm model is given by:

$$
Q=Q_{m} b C_{e} / 1+b C_{e}
$$

where $\mathrm{Q}_{\max }$ is the maximum ammonium uptake $(\mathrm{mg} / \mathrm{g}), \mathrm{b}$ is the coefficient related to the affinity between the sorbent and sorbate $(\mathrm{L} / \mathrm{mg})$ and $\mathrm{C}_{\mathrm{e}}$ is the equilibrium concentration $(\mathrm{mg} / \mathrm{L})$. The linearization form of Langmuir isotherm model can be represented as:

$$
C_{e} / Q_{e}=C_{e} / Q_{m}+1 / Q_{m} b
$$

The parameter constant for Langmuir model can be obtained from the slope and intercept of a graph $\mathrm{C}_{\mathrm{e}} / \mathrm{q}_{\mathrm{e}}$ against $\mathrm{C}_{\mathrm{e}}$. Fig. 1 shows the Langmuir plot of ammonia nitrogen removal by using Jackfruit seed. Based on Table 2, the value of constant $b$ obtained is low due to the fact that jackfruit seed adsorbent has a high affinity for ammonium ion (Dawodu and Akpomie, 2014). A dimensionless constant equilibrium parameter or known as separation factor $\left(\mathrm{R}_{\mathrm{L}}\right)$ can indicate the shape of an isotherm and this given by:

$$
R_{L}=1 /\left(1+b C_{o}\right)
$$

where $\mathrm{b}(\mathrm{L} / \mathrm{mg})$ refers to the Langmuir constant and $\mathrm{C}_{\mathrm{o}}$ is initial concentration of adsorbate. $\mathrm{R}_{\mathrm{L}}$ values between 0 and 1 signifies a favorable adsorption, 0 indicates irreversible adsorption and value higher than 1 is unfavorable (Foo and Hameed, 2010) The $R_{L}$ value obtained in this study lies between 0 and 1 and this reflects upon the adsorption process of ammonium ions onto jackfruit seed was favorable. This isotherm model was found to correlated very well to the experimental data as the regression parameter $\left(\mathrm{R}^{2}\right)$ obtained is 0.9809 as presented in Table 2 .

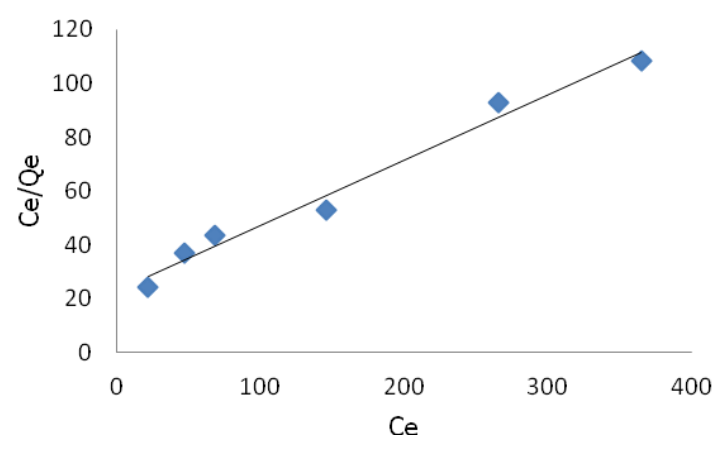

Fig. 1 Langmuir model on the adsorption of $\mathrm{NH}_{3}-\mathrm{N}$ by jackfruit seed $\left(\mathrm{pH}=7.0, \mathrm{C}_{0}=500 \mathrm{mg} / \mathrm{L}, \mathrm{M}=20 \mathrm{~g}\right)$.

Freundlich model assumes that the adsorbent has a heterogeneous surface composed of different classes of adsorption surface sites (Doulia et al., 2009). The binding strength of adsorbent surface is based on the degree of site occupation and usually surface with stronger binding sites will be occupied first (Vijayaraghavan et al., 2006). Freundlich isotherm can be applied to the multilayer adsorption, with reversible adsorption and uniform energy distribution (Gimbert et al., 2008). This isotherm model can be expressed by equation (5) and in linearization form equation (6) as follows:

$$
\begin{gathered}
Q_{e}=K_{f} C^{n} \\
\ln Q_{e}=(1 / n) \ln C_{e}+\ln K_{f}
\end{gathered}
$$

where $K_{\mathrm{f}}$ is Freundlich constant $(\mathrm{L} / \mathrm{mg})$ and $n$ is the capacity and intensity of adsorption.

A linear plot of $\ln Q_{e}$ against $\ln C_{e}$ was plotted to estimate the values of $\mathrm{K}_{\mathrm{f}}$ and $\mathrm{n}$ value from the intercept and slope of the plot respectively as shown in Fig. 2 . The value of $1 / \mathrm{n}$ obtained from the graph indicates the degree of non-linearity between the solution concentration and adsorption. The adsorption process is linear if the value of $1 / \mathrm{n}$ equal to unity and chemisorption process if the value of $1 / \mathrm{n}$ below unity. Meanwhile, a value above unity implies a favorable physical adsorption process(Gimbert et al., 2008). The value of $1 / \mathrm{n}$ obtained in this study was determined to be above unity and thus indicated that the adsorption of ammonia nitrogen onto jackfruit seed is a favorable process. The graph of Freundlich isotherm model was in good agreement as it reflects high coefficient correlation value (0.9690). The value of Freundlich isotherm constants and coefficient correlation were tabulated in Table 2 .

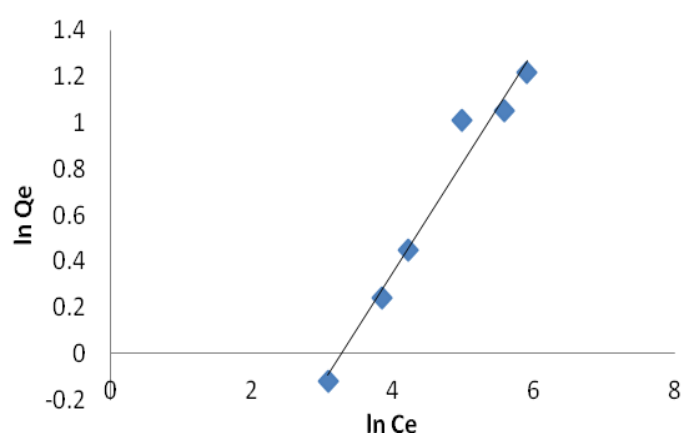

Fig. 2 Freundlich model on the adsorption of $\mathrm{NH}_{3}-\mathrm{N}$ by jackfruit seed $(\mathrm{pH}=7.0, \mathrm{Co}=500 \mathrm{mg} / \mathrm{L}, \mathrm{M}=20 \mathrm{~g}$ ). 
The experimental data also was fitted to the Temkin isotherm model and this isotherm model considered the effects of some indirect adsorbate and adsorbent interaction. This model can be represented in Equation 7 and 8 . The derivation of Temkin model equation is characterized by a uniform distribution of binding energies and in certain conditions, it can achieve maximum binding energy (Foo and Hameed, 2010).

$$
\begin{gathered}
Q_{e}=B \ln \left(A+C_{e}\right) \\
B=R T / b
\end{gathered}
$$

where B $(\mathrm{J} / \mathrm{mol})$ is Temkin constant related to the heat of adsorption and $\mathrm{A}(\mathrm{L} / \mathrm{mg})$ is the Temkin isotherm constant. Meanwhile $\mathrm{R}$ is the gas constant $(8.314 \mathrm{~J} / \mathrm{mol} \mathrm{K}), \mathrm{b}$ is Temkin isotherm constant and $\mathrm{T}$ is the temperature $(\mathrm{K})$.

Fig. 3 shows a plot of Temkin model, $Q_{e}$ versus $\ln C_{e}$ and determination of Temkin constants $\mathrm{A}$ and $\mathrm{B}$ is based on the slope and intercept of the graph. The value of B was estimated to be 0.9105 $\mathrm{J} / \mathrm{mol}$ and constant A as $0.1027 \mathrm{~L} / \mathrm{mg}$. This model assumes that the despite of concentration values, heat of adsorption of all molecules decrease linearly instead of logarithmic with coverage. This decreasing trend is due to the interactions of adsorbate and adsorbent (Gimbert et al., 2008). The coefficient correlation value of Temkin model was observed to be 0.9598 and lower compared to other isotherm models.

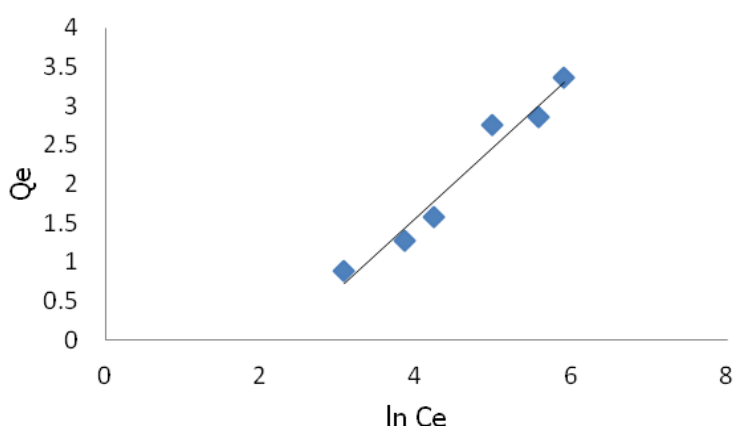

Fig. 3 Temkin model on the adsorption of $\mathrm{NH}_{3}-\mathrm{N}$ by jackfruit seed $\left(\mathrm{pH}=7.0, \mathrm{C}_{0}=500 \mathrm{mg} / \mathrm{L}, \mathrm{M}=20 \mathrm{~g}\right)$.

The Dubinin- Radushkevich (D-R) isotherm model was applied to the experimental data in order to estimate the characteristic porosity of the adsorbent and deduce the heterogeneity of the surface energies of the adsorption process (Itodo and Itodo, 2010). This isotherm model can be expressed by equation 9 below:

$$
Q_{e}=Q_{D} \exp \left(-B D\left[R T \ln \left(1+1 / C_{e}\right)\right]\right.
$$

and the linearization form of D-R isotherm model is given as:

$$
\ln Q_{e}=\ln Q_{D}-B D\left[R T \ln \left(1+1 / C_{e}\right)\right]^{2}
$$

The mean energy of sorption, $\mathrm{E}$ can be estimated by equation 11 below:

$$
E=1 /\left(2 B_{D}\right)^{1 / 2}
$$

where $\mathrm{Q}_{\mathrm{D}}$ is the $\mathrm{D}-\mathrm{R}$ model constant related to the degree of sorbate sorption by the sorbent surface $(\mathrm{mg} / \mathrm{g})$ and $\mathrm{B}_{\mathrm{D}}$ is the $\mathrm{D}-\mathrm{R}$ model constant related to the free energy of sorption per mole of the sorbate as it migrates to the surface of the sorbent $\left(\mathrm{mol}^{2} / \mathrm{kJ}^{2}\right)$. Meanwhile, $\mathrm{R}$, $\mathrm{T}$ and $\mathrm{Ce}$ represent the gas constant $(8.314 \mathrm{~J} / \mathrm{mol} \mathrm{K})$, absolute temperature $(\mathrm{K})$ and adsorbate equilibrium concentration $(\mathrm{mg} / \mathrm{L})$ respectively. Fig. 4 depict a graph of $\ln \mathrm{q}_{\mathrm{e}}$ versus $[\mathrm{RT} \ln (1+1 / \mathrm{Ce})]^{2}$ to determine the D-R parameter constants from the slope and intercept. The $\mathrm{q}_{\mathrm{D}}, \mathrm{B}_{\mathrm{D}}$ and mean energy sorption, $\mathrm{E}$ values were estimated from the graph as $0.1445 \mathrm{mg} / \mathrm{g},-0.0170 \mathrm{~mol}^{2} / \mathrm{kJ}^{2}$ and $2.6537 \mathrm{~kJ} / \mathrm{mol}$ respectively. The coefficient correlation $\left(\mathrm{R}^{2}\right)$ of $\mathrm{D}-\mathrm{R}$ model shows the lowest value compared to other isotherm model studied.

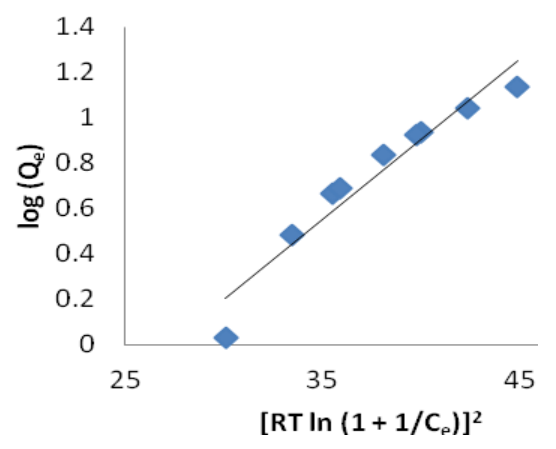

Fig. 4 Dubinin-Radushkevich model on the adsorption of $\mathrm{NH}_{3}-\mathrm{N}$ by jackfruit seed $\left(\mathrm{pH}=7.0, \mathrm{C}_{0}=500 \mathrm{mg} / \mathrm{L}, \mathrm{M}=20 \mathrm{~g}\right)$.

\section{Adsorption kinetic studies}

The adsorption process generally possessed complex mechanism and few factors influenced the process such as solid matrix, physiochemical characteristics of the adsorbent and mass transport process (Wahab et al., 2010).

Thus, by fitting the experimental data to adsorption kinetic models, the mechanism involved in the sorption process can be understand better and this is applicable for designation of large scale equipment. The mechanisms of adsorption of ammonia nitrogen onto jackfruit seed was evaluated by using three different types of kinetic models; pseudo-first order, pseudo-second order and intra-particle diffusion model.

The experimental data with different initial concentration (50, $100,500,1000 \mathrm{mg} / \mathrm{L}$ ) of ammonium solution were employed in the adsorption kinetic studies. Table 3 and 4 illustrated the mathematical equations and kinetic rate constants for each kinetic model, respectively. The important characteristics in choosing the best fitted

\begin{tabular}{|c|c|c|c|}
\hline $\begin{array}{l}\text { Kinetic } \\
\text { model }\end{array}$ & Original form & Linearized form & Plots \\
\hline $\begin{array}{l}\text { Pseudo- } \\
\text { first order }\end{array}$ & $d Q_{t} / d t=k_{1}\left(Q_{e}-Q_{t}\right)$ & $\ln \left(Q_{\mathrm{e}}-Q_{\mathrm{t}}\right)=\ln \mathrm{Q}_{\mathrm{e} 1}-\mathrm{k}_{1} \mathrm{t}$ & $\begin{array}{c}\ln \left(Q_{e}-Q_{t}\right) v s \\
t\end{array}$ \\
\hline $\begin{array}{l}\text { Pseudo- } \\
\text { second } \\
\text { order }\end{array}$ & $\mathrm{dQ}_{\mathrm{t}} / \mathrm{dt}=\mathrm{k}_{2}\left(\mathrm{Q}_{\mathrm{e}}-\mathrm{Q}_{\mathrm{t}}\right)^{2}$ & $\begin{aligned} t / Q_{t}= & \left(1 / k_{2} Q_{e l l}^{2}\right)+ \\
& \left(1 / Q_{e l l}\right) t\end{aligned}$ & $t / Q_{t} v s t$ \\
\hline $\begin{array}{l}\text { Intra- } \\
\text { particle } \\
\text { diffusion }\end{array}$ & $\mathrm{Q}_{\mathrm{t}}=\mathrm{k}_{\mathrm{p}} \mathrm{V}_{\mathrm{t}}$ & $\mathrm{Q}_{\mathrm{t}}=\mathrm{k}_{\mathrm{p}} \mathrm{Vt}_{\mathrm{t}}$ & $Q_{t}$ vs $\sqrt{ } t$ \\
\hline
\end{tabular}
kinetic model is based on the value of linear regression correlation coefficient $\left(\mathrm{R}^{2}\right)$ and the calculated equilibrium adsorption capacity $\left(q_{e}\right)$.

\begin{tabular}{|c|c|c|c|c|}
\hline & \multicolumn{4}{|c|}{ Initial concentration $(\mathrm{mg} / \mathrm{L})$} \\
\hline & 50 & 100 & 500 & 1000 \\
\hline Experimental $Q_{e}(\mathrm{mg} / \mathrm{g})$ & 0.07 & 0.29 & 3.37 & 1.34 \\
\hline $\begin{array}{l}\text { Pseudo first order } \\
k_{1}\left(m^{-1}\right)\end{array}$ & 0.01 & -0.04 & 0.02 & 0.02 \\
\hline Calculated $Q_{e}\left(\mathrm{mg} \mathrm{g}^{-1}\right)$ & 0.52 & $\begin{array}{r}-0.04 \\
0.12\end{array}$ & $\begin{array}{l}0.02 \\
1.66\end{array}$ & 0.97 \\
\hline $\begin{array}{l}\mathrm{R}^{2} \\
\text { Pseudo second order }\end{array}$ & 0.34 & 0.23 & 0.70 & 0.19 \\
\hline $\mathrm{k}_{2}\left(\mathrm{~min}^{-1}\right)$ & -0.08 & -0.07 & 0.08 & 0.04 \\
\hline Calculated $Q_{e}\left(\mathrm{mg} \mathrm{g}^{-1}\right)$ & 0.04 & 0.21 & 2.97 & 1.69 \\
\hline $\mathrm{R}^{2}$ & 0.85 & 0.96 & 0.92 & 0.62 \\
\hline Intra-particle diffusion & & & & \\
\hline $\mathrm{K}_{\mathrm{p}}\left(\mathrm{mg} \mathrm{g}^{-1} \min ^{-0.5}\right)$ & 0.14 & 0.14 & 0.21 & 0.14 \\
\hline$R^{2}$ & 0.92 & 0.92 & 0.80 & 0.92 \\
\hline
\end{tabular}

Table 3 Mathematical equations of kinetic models.

Table 4 Kinetic rate constant for biosorption of ammonia nitrogen onto jackfruit seeds adsorbent. 
A graph of $\ln (\mathrm{Qe}-\mathrm{Qt})$ against time $(\mathrm{t})$ is plotted to evaluate the fitting of experimental data to pseudo first order kinetic model. Based on Fig. 5, the pseudo-first order model did not adequately fit to the experimental data at all different concentrations as the coefficient correlation values obtained were very low and besides, the difference between the experimental and calculated $\mathrm{Q}_{\mathrm{e}}$ values are very high as presented in Table 4.

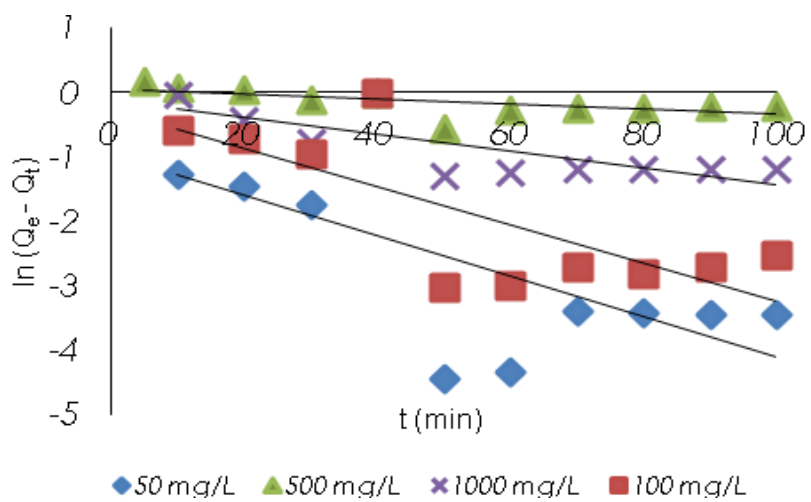

Fig. 5 Pseudo first order kinetic model.

On the contrary, the coefficient correlation $\left(\mathrm{R}^{2}\right)$ acquired from a linear plot of $\mathrm{t} / \mathrm{Q}_{\mathrm{t}}$ against $t$ shows the highest values compared to other kinetic models as presented in Table 3. In addition, the calculated $Q_{e}$ values for this kinetic model have the closest values to the experimental values. These well fitted results eventually make the pseudo second order as the best kinetic model to represent the biosorption of ammonium ions onto jackfruit seed adsorbent. Fig. 6 shows a linear plot of pseudo second order kinetic model. This model assumes that the adsorption process of ammonium ion is governed by chemical sorption and involving sharing and exchange of electrons between the adsorbent and adsorbate (Yaser et al., 2016). This result is in accordance to previous studies on the biosorption of ammonium ions onto adsorbent (Chen and Chai, 2008) (Wahab et al., 2010) (Liu et al., 2010)

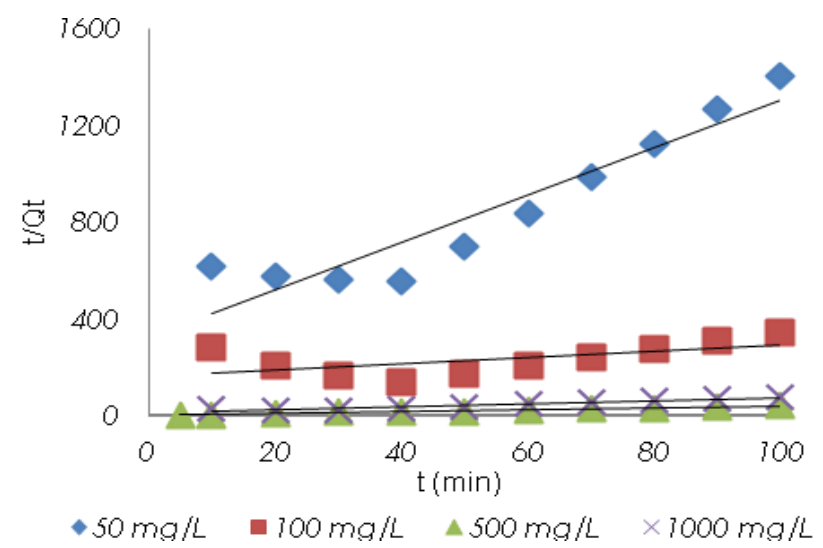

Fig. 6 Pseudo second-order kinetic models.

Intra-particle diffusion model is employed to identify the step governing involved in the adsorption process. The equation of intraparticle model can be expressed as given in Table 3. Fig. 7 depict a linear plot of $\mathrm{Q}_{\mathrm{t}}$ versus $\mathrm{t}^{1 / 2}$ at different concentrations. The slope of the graph can determine the rate constant of intra-particle diffusion model $\left(\mathrm{k}_{\mathrm{p}}\right)$ whereas the graph intercept reflects the boundary layer effect.

The rate constant and coefficient correlation values are listed in Table 4. In this study, the linear plots at all studied concentrations did not passing through the origin and thus indicated that the intra-particle diffusion is not only the rate limiting steps involved in the adsorption of ammonia nitrogen by jackfruit seed. The linear plot depicted a multi-linearity relation and suggests that the biosorption of ammonium ions onto the jackfruit seed involves more than one process.
The earlier stage involves surface adsorption or instantaneous adsorption which correlated to the boundary layer diffusion of adsorbate meanwhile the second phase is attributed to the intraparticle diffusion occur within the pore of jackfruit seed adsorbent. The last section of the curves with null slope distinguished the final equilibrium stage where the intra-particle diffusion starts to slow down due to low adsorbate concentration in the aqueous solution $(\mathrm{Gu}$ et al., 2011). Several studies on biosorption process onto bio-sorbent revealed to have the same adsorption stages involved (Jellali et al., 2011); (Abramian and El-Rassy, 2009).

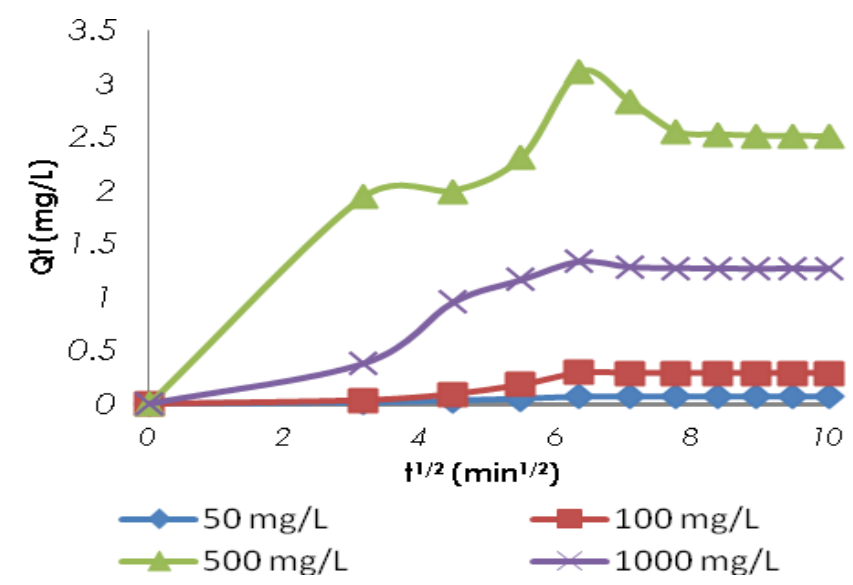

Fig. 7 Intra-particle diffusion kinetic models.

\section{CONCLUSION}

In this study, the isotherm and kinetic studies of ammonia nitrogen removal by jackfruit seed adsorbent were evaluated by fitting the experimental data obtained into few types of isotherm and kinetic models. The adsorption isotherm data fitted well Langmuir model with correlation $\left(\mathrm{R}^{2}\right)$ of 0.9809 . Meanwhile, the kinetic study follows pseudo-second order model as the plot exhibited high coefficient correlation $\left(\mathrm{R}^{2}\right)$ values ranges from 0.62 to 0.96 for various concentration. Furthermore, the calculated adsorption capacity $\left(\mathrm{Q}_{\mathrm{e}}\right)$ for this model has the closest value to the experimental values. Thus, these results indicated that the adsorption process involves sharing or exchange of cations between the adsorbent and adsorbate in the solution. This study can be concluded that ammonia nitrogen can be removed from aqueous solution by using jackfruit seed adsorbent.

\section{ACKNOWLEDGEMENT}

This study was financially supported by Ministry of Higher Education Malaysia and University Malaysia Sabah under research Project Grant FRG0420-TK-1/2015.

\section{REFERENCES}

Abramian, L., El-Rassy, H. 2009. Adsorption kinetics and thermodynamics of azo-dye Orange II onto highly porous titania aerogel. Chem. Eng. J. 150(2), 403-410.

Cengiz, S., Tanrikulu, F., Aksu, S. 2012. An alternative source of adsorbent for the removal of dyes from textile waters: Posidonia oceanica (L.). Chem. Eng. J. 189, 32-40.

Chen, Y. N., Chai, L. Y. 2008. Comparison for adsorption modeling of heavy metals $(\mathrm{Cd}, \mathrm{Pb}, \mathrm{Cu}, \mathrm{Zn})$ from aqueous solution by bio-formulation. Paper presented at the 2nd International Conference on Bioinformatics and Biomedical Engineering (ICBBE 2008), Shanghai, China: IEEE, 32483251 .

Choy, S. Y., Prasad, K. M. N., Wu, T. Y., Raghunandan, M. E., Yang, B., Phang, S.-M., Ramanan, R. N. 2017. Isolation, characterization and the potential use of starch from jackfruit seed wastes as a coagulant aid for treatment of turbid water. Environ. Sci. and Pollution Res. 24(3), 28762889. 
Dawodu, F. A., Akpomie, K. G. 2014. Simultaneous adsorption of Ni(II) and $\mathrm{Mn}(\mathrm{II})$ ions from aqueous solution unto a Nigerian kaolinite clay. $J$. Mater. Res. Tech. 3(2), 129-141.

Doulia, D., Leodopoulos, C., Gimouhopoulos, K., Rigas, F. 2009. Adsorption of humic acid on acid-activated Greek bentonite. J. Colloid Interface Sci. 340(2), 131-141.

Foo, K. Y., Hameed, B. H. 2010. Insights into the modeling of adsorption isotherm systems. Chem. Eng. J. 156(1), 2-10.

Gimbert, F., Morin-Crini, N., Renault, F., Badot, P.-M., Crini, G. 2008 Adsorption isotherm models for dye removal by cationized starch-based material in a single component system: error analysis. J. Hazard. Mater. 157(1), 34-46.

Gu, L., Xu, J., Lv, L., Liu, B., Zhang, H., Yu, X., Luo, Z. 2011. Dissolved organic nitrogen (DON) adsorption by using Al-pillared bentonite. Desalination, 269(1), 206-213.

Ibrahim, A., Yusof, L., Beddu, N. S., Galasin, N., Lee, P. Y., Lee, R. N. S., Zahrim, A. Y. 2016. Adsorption study of Ammonia Nitrogen by watermelon rind. IOP Conference Series: Earth and Environmental Science, 36, 012020.

Ibrahim, A., Yusof, L., Yaser, Z. A. 2017. Ammonia nitrogen removal from aquoues solution by local agricultural wastes. IOP Conference Series: Materials Science and Engineering, 206(1), 012077.

Itodo, A. U., Itodo, H. U. 2010. Sorption energies estimation using DubininRadushkevich and Temkin adsorption isotherms. Life Sci. J.-Acto Zhengzhou University Overseas Edition, 7(4), 31-39.

Jellali, S., Wahab, M. A., Anane, M., Riahi, K., Jedidi, N. 2011. Biosorption characteristics of ammonium from aqueous solutions onto Posidonia oceanica (L.) fibers. Desalination, 270(1), 40-49.

Lee, R. N. S., Shahril, Y., Bolong, N., Yaser, Z. A. (2016). Ammonia-nitrogen removal from urban drainage using modified fresh empty fruit bunches: A case study in Kota Kinabalu, Sabah. Paper presented at the International Conference on Chemical and Bioprocess Engineering, Sabah, Malaysia, 012055.
Liu, H., Dong, Y., Liu, Y., Wang, H. 2010. Screening of novel low-cost adsorbents from agricultural residues to remove ammonia nitrogen from aqueous solution. J. Hazard. Mater. 178(1-3), 1132-1136.

Ma, Z., Li, Q., Yue, Q., Gao, B., Li, W., Xu, X., Zhong, Q. 2011. Adsorption removal of ammonium and phosphate from water by fertilizer controlled release agent prepared from wheat straw. Chem. Eng. J. 171(3), 12091217.

Ramasamy, S., Krishnamoorthy, S. 2015. Isotherm, kinetic, and thermodynamic studies on $\mathrm{Ni}$ (II) removal from aqueous solution by Citrus limettioides seed and its carbon derivative. Environ. Prog. \& Sustain. Energy, 34(5), 1384-1395.

Rengsutthi, K., Charoenrein, S. 2011. Physico-chemical properties of jackfruit seed starch (Artocarpus heterophyllus) and its application as a thickener and stabilizer in chilli sauce. LWT-Food Sci. Tech. 44(5), 1309-1313.

Singh, H., Chauhan, G., Jain, A. K., Sharma, S. K. 2017. Adsorptive potential of agricultural wastes for removal of dyes from aqueous solutions. $J$. of Environ. Chem. Eng. 5(1), 122-135.

Sudha, R., Srinivasan, K., Premkumar, P. 2015. Removal of nickel(II) from aqueous solution using Citrus Limettioides peel and seed carbon. Ecotoxicol. Environ. Saf. 117, 115-123.

Vijayaraghavan, K., Padmesh, T. V. N., Palanivelu, K., Velan, M. 2006. Biosorption of nickel(II) ions onto Sargassum wightii: Application of two-parameter and three-parameter isotherm models. J. Hazard. Mater. 133(1-3), 304-308.

Wahab, M. A., Jellali, S., Jedidi, N. 2010. Effect of temperature and pH on the biosorption of ammonium onto Posidonia oceanica fibers: Equilibrium, and kinetic modeling studies. Bioresource Tech. 101(22), 8606-8615.

Yaser, Z. A., Yusof, L., Lee, R. N. S., Ibrahim, A. 2016. Fruit waste adsorbent for ammonia nitrogen removal from synthetic solution: Isotherms and kinetics. Paper presented at the International Conference on Chemical and Bioprocess Engineering, Sabah, Malaysia, 012028. 